\title{
Działalność wydawnictwa M. Arcta na rzecz popularyzowania wiedzy na początku XX w. na przykładzie serii „Książki dla Wszystkich” i „Biblioteczka Dzieł Społeczno-Ekonomicznych”
}

W dziejach polskiej kultury w wiekach XIX i XX ruch wydawniczy odgrywał szczególną rolę. W Królestwie Polskim, wobec braku polskiego uniwersytetu i instytucji naukowych, stanowił jeden z ważnych środków oddziaływania społecznego. Jego rola w zakresie upowszechniania nauki była nie do przecenienia. Działalność popularyzatorska szła w parze z szerszą działalnością społeczną; jak zaznacza Henryk Markiewicz, „wybory wydawców zawodowych były określone celami komercyjnymi; ambitniejsi spośród nich starali się jednak zharmonizować z nimi obowiązki narodowo-społeczne"1. Jednocześnie wydawcy tworzyli ważne centra kultury i nauki, a siedziby ich wydawnictw i prywatne mieszkania były miejscami spotkań uczonych i publicystów².

Jedną z najbardziej zasłużonych dla rozwoju polskiej kultury w dobie zaborów była rodzina Arctów, prowadząca działalność księgarską i wydawniczą. Niektórzy badacze uważają, że rodzina ta była pochodzenia niemieckiego, wyznania ewangelickiego ${ }^{3}$. Jednak nestor rodu to osiadły w Lublinie Żyd, Mojżesz Rofe, z zawodu lekarz, pochodzący z Zamościa, który w 1857 r., w wieku 73 lat przyjął chrzest w obrządku ewangelicko-reformowanym, zmieniając imię na Michał . Jego potomkowie ulegli całkowitej polonizacji, zmienili także wyznanie na katolickie. Najmłodszy syn Michała Arcta, Stanisław (pierwotnie Samuel), założył w Lublinie

* Dr, Uniwersytet Łódzki, Wydział Nauk o Wychowaniu, Katedra Historii Wychowania i Pedeutologii, 91-408 Łódź, ul. Pomorska 46/48.

1 H. Markiewicz, Pozytywizm, Warszawa 2008, s. 32.

2 M. Micińska, Inteligencja na rozdrożach 1864-1918, Warszawa 2008, s. 102-103.

3 A. Chwalba, Historia Polski 1795-1918, Kraków 2000, s. 322.

4 M. Mlekicka, Wydawcy książek w Warszawie w okresie zaborów, Warszawa 1987, s. 180. 
w 1836 r. księgarnię ${ }^{5}$. Równolegle od roku 1852 rozszerzał profil firmy o działalność wydawniczą. Rozpoczął od skupywania nakładów innych wydawnictw, opatrując je swoimi sygnaturami. Na takiej zasadzie nabył zawierającą 12 tomów serię „Biblioteka Popularna Nauk Przyrodzonych”. W 1862 roku współpracę z firmą Stanisława Arcta rozpoczął syn najstarszego z potomków nestora rodu, Franciszka - Michał Arct, który po ukończeniu gimnazjum odbył praktykę w lubelskiej księgarni stryja. Później poszerzał kwalifikacje zawodowe podczas praktyki w Berlinie, m.in. w firmie wydawniczej Behr\&Bock. Po powrocie do Królestwa w 1864 r. Michał Arct objął kierownictwo księgarni lubelskiej. Arctowie rozbudowywali rodzinną firmę, duży nacisk kładąc na działalność wydawniczą, związaną zwłaszcza z potrzebami oświaty i szkolnictwa. Bardzo cennym przedsięwzięciem wydawniczym było opublikowanie w latach 1872-1875 cyklu podręczników wybitnego pedagoga i nauczyciela w prywatnych domach, Augusta Jeskego. Jeske za niezbędne uważał opracowanie odpowiadających ówczesnemu stanowi wiedzy pedagogicznej podręczników do nauczania elementarnego. Opracował koncepcję szeroko zakrojonej serii wydawnictw pedagogicznych pt. „Systematyczny kurs nauk przeznaczonych do pomocy w wychowaniu domowym dla dzieci od lat 3 do 15 ". W założeniu seria miała liczyć 29 książek obejmujących trzy okresy nauczania: przedelementarny (dla dzieci w wieku 3-7 lat), elementarny niższy (dla dzieci w wieku 7-10 lat), elementarny wyższy (dla dzieci w wieku do 15 lat). Ciężki stan zdrowia i przedwczesna śmierć Jeskego w wieku 39 lat uniemożliwiły realizację całego przedsięwzięcia ${ }^{6}$. Ostatecznie udało się opublikować 12 książek. Podręczniki te miały być podstawą nauczania elementarnego w pełnym zakresie, uzupełnione były także wskazówkami metodycznymi. W kolejnych latach podręczniki były wielokrotnie wznawiane, odgrywały ważną rolę w praktyce edukacyjnej i upowszechnianiu wiedzy na poziomie elementarnym.

Kolejny etap w rozwoju firmy nastąpił po odstąpieniu jej w całości przez Stanisława Arcta, w zamian za dożywotnią rentę, na rzecz Michała Arcta, w roku 1881 r. Odtąd firma nosiła nazwę M. Arct. W 1887 r. Michał Arct kupił warszawską księgarnię Artura Gruszeckiego i przeniósł się do Warszawy, prowadzenie księgarni w Lublinie pozostawiając ciotce Teofili. Troszcząc się o obie księgarnie, kontynuował jednocześnie działalność wydawniczą, szczególną wagę przykładając do publikacji związanych z edukacją, wychowaniem i szkolnictwem ${ }^{7}$. Michał Arct był więc drugą w rodzinie osobą łączącą zawód księgarza i wydawcy książek ${ }^{8}$. W 1892 r. pracę w firmie podjął syn Michała, Zygmunt Arct, który wcześniej odbył studia handlowe w Dreźnie. Po śmierci ojca w 1916 r. przejął kierownictwo w przedsiębiorstwie, kontynuując działalność wydawniczą9. Arcto-

${ }^{5}$ S. Arct, Okruchy wspomnień, Warszawa 1962, s. 59.

6 I. Łapinowa, Jeske August Adam, [w:] Polski Stownik Biograficzny, t. 11, red. B. Leśnodorski, Wrocław 1964-1965, s. 192-93.

7 J. Muszkowski, Arct Michał, [w:] Polski Słownik Biograficzny, t. 1, red. W. Konopczyński, Kraków 1935, s. 155.

${ }^{8}$ Arctowie, [w:] Encyklopedia wiedzy o książce, red. A. Birkenmajer, B. Kocowski, J. Trzynadlowski, Wrocław 1971, s. 70-73.

${ }_{9}^{9}$ M. Mlekicka, Wydawcy warszawscy w XIX w. jako grupa społeczna $i$ ich związki z inteligencją, [w:] Inteligencja polska XIX i XX wieku. Studia 4, red. R. Czepulis-Rastenis, Warszawa 1985, s. 25. 
wie byli jednymi z tych wydawców, którzy wyróżniali się działalnością społeczną i bezpłatnym przekazywaniem książek na potrzeby czytelników. W 1913 roku Michał Arct ofiarował 150 tys. egzemplarzy książek z serii „Książki dla Wszystkich” dla bezpłatnych czytelni i kółek rolniczych na terenie Królestwa Polskiego, Galicji i Wielkiego Księstwa Poznańskiego. Powołany przy tym został komitet, w skład którego weszli znani działacze społeczni, którzy byli odpowiedzialni za rozdysponowanie ofiarowanych przez wydawcę książek ${ }^{10}$.

Wymieniona wyżej seria „Książki dla Wszystkich”, zainicjowana w 1898 r., była jednym z najbardziej znaczących długotrwałych wydawnictw seryjnych, stawiającym sobie za cel popularyzowanie wiedzy. Do 1905 r. opublikowano ok. 300 tomów, do 1913 r. ok. 600 tomów. Jak stwierdza L. Zasztowt, „była to największa seria popularnonaukowa wydawana na ziemiach polskich"11. Seria była bardzo zróżnicowana, zarówno jeśli chodzi o zakres tematyczny, jak i merytoryczny poziom poszczególnych części. Krytycznie, ale nie bezzasadnie pisano o tego rodzaju przedsięwzięciach na łamach „Prawdy” w 1904 r.: „Dotychczasowe zabiegi szerzenia wiedzy za pomocą książek i uniwersytetów ludowych mają tę wielką wadę, że nie obejmują ani całokształtu poznania, ani nawet jednej jego dziedziny. Wydawnictwa i wykład tego rodzaju nie stanowią łańcucha ogniw ściśle spojonych, ale szereg niepowiązanych i luźno obok siebie stojących ułamków. Kawałek historyi, kawałek biologii, kawałek ekonomii politycznej, kawałek lingwistyki itd. - oto zwykły szereg takich popularyzacji"12.

Zakres przedmiotowy serii „Książki dla Wszystkich” był bardzo szeroki. Obejmował literaturę piękną, w tym poezję i prozę, zarówno polskich, jak i obcych twórców. Ta kategoria została rozbudowana jeszcze bardziej po 1905 r., kiedy udział tomów beletrystycznych i poetyckich wzrósł w stosunku do opracowań o charakterze popularnonaukowym. Ogółem ok. połowy serii stanowiły publikacje z różnych dziedzin wiedzy. Jak wspomniano, problemem serii był nierówny poziom publikacji. Naturalnie, główny wpływ na to miało przygotowanie autorów poszczególnych tomów. Z jednej strony z wydawnictwem współpracowali bowiem znakomici specjaliści, często młodzi adepci różnych dziedzin nauki, o których pisali, opracowując tomy „Książek dla Wszystkich”, z drugiej autorzy nieposiadający wystarczającego merytorycznego przygotowania. Do grupy zdolnych autorów współpracujących z wydawnictwem M. Arcta należeli m.in. Władysław Smoleński, Tadeusz Korzon, Natalia Gąsiorowska, by wymienić choćby autorów prac historycznych, wybitnych uczonych w swej dziedzinie. Pisano o wydarzeniach i procesach historycznych, wykorzystując najnowsze ustalenia polskiej i obcej historiografii ${ }^{13}$. Osobną grupę prac stanowiły opracowania z zakresu

10 H. Chamerska, Mecenat biblioteczny w Polsce okresu zaborów, [w:] Inteligencja polska XIX i XX wieku. Studia 6, red. R. Czepulis-Rastenis, Warszawa 1991, s. 66.

11 L. Zasztowt, Popularyzacja nauki w Królestwie Polskim 1864-1905, Wrocław 1989, s. 114.

12 Pamiętnik. Z chwili, „Prawda” 1904, nr 15, s. 175.

13 Zob. m.in. W. Smoleński, Rządy pruskie na ziemiach polskich 1793-1807, Warszawa 1903; M. Offmański, Grunwald: monografia historyczna, Warszawa 1903; N. Gąsiorowska, Historja zakonów w Polsce, Warszawa 1910; W. Służewski, Zarys historji handlu w Polsce, Warszawa 1910; E. Łuniński, Przed wyprawą wiedeńską: Studjum historyczne, Warszawa 1905; J. K. Kochanowski, Początki walki słowiańsko-niemieckiej nad Bałtykiem w świetle najnowszej historiografji niemieckiej, Warszawa 1901. 
historii oświaty ${ }^{14}$. Trzeba tu podkreślić, że prace te popularyzowały aktualny dorobek polskiej nauki w tym zakresie. Na początku XX w. kształtowała się bowiem na niwie polskiej nauki historycznej osobna dyscyplina badawcza - historia kultury, w ramach której wyodrębniła się historia szkolnictwa i oświaty. Refleksja historyczno-kulturalna i historyczno-oświatowa powoli przybierała w pełni naukowy wymiar, co pozwoliło na wyodrębnienie samodzielnej dziedziny nauki, potwierdzało zarazem przeobrażenia polskiej nauki historycznej w duchu mutacji modernistycznej (według określenia Jolanty Kolbuszewskiej) ${ }^{15}$. Już w pierwszym okresie stopniowego usamodzielniania się historii oświaty, dzięki pracom Ignacego Chrzanowskiego i Stanisława Krzemińskiego, dążono do popularyzacji tej dyscypliny nie tylko wśród profesjonalistów, ale też wśród szerokiego grona czytelników.

Do współpracowników wydawnictwa należała Zofia Daszyńska-Golińska, autorka kilku tomów serii, specjalistka w zakresie ekonomii, historii gospodarczej, nauk społecznych, demografii, pierwsza w Polsce kobieta, która skończyła studia ekonomiczne. Kilkanaście tomów opracował Stanisław Brzozowski, zdolny krytyk literacki, pisarz i publicysta, erudyta o wielkiej wiedzy w zakresie literatury, filozofii, nauk społecznych, wybitna indywidualność intelektualna swych czasów ${ }^{16}$. Oskarżany o współpracę z rosyjskimi służbami bezpieczeństwa, przez wielu działaczy został uznany za prowokatora, mimo braku dowodów na jego działalność agenturalną. Miał on poważne problemy zdrowotne i finansowe, a jednym z najważniejszych źródeł jego utrzymania była twórczość pisarska i popularyzatorska, imponująca rozległością podejmowanych problemów, a jednocześnie wysokim poziomem artystycznym i merytorycznym. Ten ostatni aspekt był szczególnie ważny podczas rozpoczętej w maju 1901 r. współpracy z wydawnictwem Arcta ${ }^{17}$. Tomy opublikowane przez Brzozowskiego w ramach omawianej serii wysoko cenili specjaliści za oryginalność i rozległą wiedzę autora ${ }^{18}$.

Wartościowe tomy wychodziły także spod ręki autorów, którzy z racji doświadczenia pedagogicznego i publicystycznego potrafili przygotować przystępne opracowania, dostosowane do potrzeb przeciętnego odbiorcy. Autorem kilku prac poświęconych twórczości wybitnych polskich pisarzy i poetów (tomy dotyczące Aleksandra Świętochowskiego, Marii Konopnickiej, Adama Asnyka) był Henryk Galle, pedagog, historyk literatury, krytyk literacki, zasłużony właśnie na polu popularyzacji literatury. Pisała o nim Zofia Rothertowa: „nie wybitny, ale bardzo sumienny i pracowity, zaznaczył się pozytywnie w polskim życiu literackim i oświatowym"19. Podobnie pracę pedagogiczną i publicystyczną z popularyzacją

14 I. Chrzanowski, Wielka reforma szkolna Konarskiego: Odczyt popularny, Warszawa 1908; S. Krzemiński, Kommissya Edukacyjna: Odczyt, Warszawa 1908.

15 J. Kolbuszewska, Mutacja modernistyczna w historiografii polskiej (przełom XIX i XX wieku), Łódź 2005.

16 A. Hutnikiewicz, Młoda Polska, Warszawa 2001, s. 336.

17 K. Wyka, Brzozowski Leopold Stanisław Leon, [w:] Polski Słownik Biograficzny, red. W. Konopczyński, t. 3, Kraków 1937, s. 62.

18 S. Brzozowski, Jan Śniadecki, życie i dzieła, Warszawa 1904; tenże, Hipolit Taine jako estetyk i krytyk, Warszawa 1902; tenże, Stanisław Wyspiański jako poeta, Warszawa 1903.

19 Z. Rothertowa, Galle Henryk, [w:] Polski Słownik Biograficzny, t. 7, red. W. Konopczyński, Kraków 1948-1958, s. 233. 
wiedzy łączył Florian Łagowski ${ }^{20}$. Jego opracowania dotyczące historii literatury polskiej były bardzo wysoko cenione ${ }^{21}$. Ten sam autor opublikował także kilka prac poświęconych życiorysom wybitnych postaci polskiej kultury (m.in. Janowi Kochanowskiemu, Ignacemu Krasickiemu, Kazimierzowi Brodzińskiemu) ${ }^{22}$. Właśnie opracowania z zakresu historii literatury polskiej prezentowały bardzo wysoki poziom merytoryczny, łącząc zalety prac popularyzatorskich z naukowym charakterem. Remigiusz Kwiatkowski przygotował kilka opracowań dotyczących literatury na świecie ${ }^{23}$.

Dużym zainteresowaniem czytelników cieszyła się biografistyka, co zresztą nie było w owym czasie tylko specyfiką polskiego społeczeństwa. W polskich warunkach jednak nabierała ona jeszcze większego znaczenia. Dużą popularność zyskiwała indywidualistyczno-heroistyczna wizja przeszłości, służąca próbie stworzenia panteonu narodowego. Refleksja o historii, literaturze łączyła się często z podejściem personalistycznym, a to sprzyjało podejmowaniu opracowań biograficznych. W serii „Książki dla Wszystkich” biografie sławnych ludzi stanowiły niemałą część; prócz wspomnianych wyżej postaci pisano m.in. o Jędrzeju Śniadeckim, Fryderyku Chopinie, Stanisławie Moniuszce ${ }^{24}$. Powstały tomy poświęcone Mikołajowi Rejowi, Maurycemu Mochnackiemu, Józefowi Ignacemu Kraszewskiemu, Marii Konopnickiej, Elizie Orzeszkowej. Maria Buyno-Arctowa napisała tom poświęcony życiu i dziełom Narcyzy Żmichowskiej, zmarłej niespełna trzydzieści lat wcześniej25.

Prócz opracowań podstaw nauk humanistycznych i słowników języków obcych omawiana seria prezentowała aktualny stan wiedzy z dziedziny nauk przyrodniczych i społecznych. Wydawano tomy z zakresu chemii i fizyki oraz astronomii $^{26}$. Opublikowano cenne opracowanie geografii fizycznej autorstwa Wacława Nałkowskiego i podręcznik geografii Europy przygotowany przez W. Janusza $^{27}$. Osobne tomy serii systematyzowały informacje na temat miar, wag, systemu monetarnego ${ }^{28}$. Ważną rolę odgrywały prace poświęcone problemom

20 A. Szycówna, Florjan Łagowski, „Nowe Tory” 1909, nr 1, s. 102.

21 F. Łagowski opublikował osiem tomów serii pt. Historia literatury polskiej w zarysie. Każdy poświęcony był kolejnej epoce; pierwszy tom cyklu został wydany w 1902 r. i dotyczył dziejów literatury polskiej do XVI w., ostatni, wydany w 1909 r., obejmował okres po 1863 r.

22 F. Łagowski, Ignacy Krasicki i jego dzieła: w stuletnią rocznicę, Warszawa 1902; F. Łagowski, Jan Kochanowski i jego dzieła, Warszawa 1901; F. Łagowski, Kazimierz Brodziński, Warszawa 1901.

${ }^{23}$ R. Kwiatkowski opublikował w ramach serii kilka tomów: Literatura chińska, Literatura japońska, Literatura egipska, Literatura indyjska, Literatura arabska.

24 S. Brzozowski, Jędrzej Śniadecki: jego życie i dzieła, Warszawa 1903; A. Arct, Fryderyk Chopin, jego życie i dzieła: podług Karasowskiego, Liszta i innych, Warszawa 1901; A. Arct, Stanisław Moniuszko, jego życie i dzieła: z różnych źródeł, Warszawa 1902; J. Nitowski, Józef Ignacy Kraszewski i jego dzieła, Warszawa 1905; J. Nitowski, Eliza Orzeszkowa, Warszawa 1903.

25 M. Bujno, Narcyza Żmichowska (Gabryela) i jej dzieła, Warszawa 1902.

26 S. Bouffałł, Woda pod względem fizycznym i chemicznym, Warszawa 1901; tenże, Powietrze, Warszawa 1902; tenże, Zasady mechaniki jako wstęp do nauki fizyki, Warszawa 1903; A. D. Bernstein, O obrocie ziemi dokoła osi, Warszawa 1904.

27 W. Nałkowski, Mała geografia fizyczna. Zarys, Warszawa 1905; W. Janusz, Podręczna gieografia Europy, Warszawa 1909.

${ }_{28}$ Z. Kamiński, Miary i wagi wszystkich krajów na kuli ziemskiej, Warszawa 1901; tenże, Pieniądze, ich powstanie, rozwój i stan dzisiejszy, Warszawa 1901. 
rozwoju społecznego, rozpatrywanego w różnych aspektach. W. M. Kozłowski napisał tom dotyczący życia społecznego i systemu władzy Stanów Zjednoczonych Ameryki Północnej ${ }^{29}$. Zofia Daszyńska-Golińska opublikowała tom poświęcony kwestiom demograficznym, pragnąć spopularyzować wśród szerokiego grona czytelników tę młodą gałąź nauki, jej podstawowe pojęcia, założenia i cele. Kwestie demograficzne uznawała za szczególnie ważne, wskazywała na zależności między sytuacją polityczno-gospodarczą a przebiegiem zjawisk i procesów demograficznych oraz związki między polityką społeczną a demografią. Wynikało to z przeświadczenia, że obie te dziedziny dotyczą zjawisk społecznych o charakterze masowym ${ }^{30}$. Zwracano także uwagę na miejsce i rolę kobiet w życiu społecznym ${ }^{31}$.

Wydawane były tomy, które za zadanie miały popularyzowanie wiedzy zdrowotno-higienicznej, co było formą realizacji ideału pracy organicznej, zakładającego walkę z przesądami i zabobonami, upowszechnianie higienicznego stylu życia, budowanie klimatu sprzyjającego zmianom społecznej mentalności i akceptacji nowych zasad dotyczących zdrowia i higieny ${ }^{32}$. Tomy poświęcone tej problematyce promowały aktualną wiedzę dynamicznie rozwijających się w XIX w. dyscyplin, co było ważnym elementem w praktycznym przełożeniu najnowszych osiągnięć naukowych na potrzeby szerokiego odbiorcy. Prócz propagowania teoretycznej wiedzy dbano także o publikowanie tomów zawierających konkretne, praktyczne informacje; wydano np. przystępnie napisany poradnik pt. Uwagi i rady lekarza przydatne $w \dot{z ̇ y c i u ~ c o d z i e n n e m}{ }^{33}$. Osobną grupę publikacji stanowiły poradniki poświęcone zdrowiu i higienie dzieci i młodzieży. Opublikowano m.in. cieszące się dużą popularnością poradniki: Bronisława Handelsmana Wskazówki dla rodziców $i$ wychowawców dotyczące pielęgnowania zdrowia uczącej się młodzieży oraz Bohdana Korybuta-Daszkiewicza Pielęgnowanie chorego dziecka ${ }^{34}$. Wielką wartość miały broszury poświęcone zdrowiu dzieci autorstwa świetnego warszawskiego lekarza, Jana Bączkiewicza ${ }^{35}$.

${ }^{29}$ W. M Kozłowski, Jak jest za oceanem: urządzenia państwowe i życie społeczne Stanów Zjednoczonych Ameryki Północnej, Warszawa 1902.

30 Z. Daszyńska-Golińska, Nauka o ludności, Warszawa 1902.

31 W. Marrené-Morzkowska, Kobieta czasów obecnych, Warszawa 1903; Antoszka (A. Smišková), Działalność kobiet czeskich i ich udział w odrodzeniu Czech, Warszawa 1903; H. Dohm, Z dziejów ruchu kobiecego, Warszawa 1904.

32 E. Fülly, Jak zachować zdrowie, urodę i młodość: praktyczne rady dla naszych córek, Warszawa 1901; tenże, Jak zachować zdrowie, urodę i młodość: praktyczne rady dla kobiet, Warszawa 1902; L. Wolberg, Krótka anatomja ciała ludzkiego, Warszawa 1904; S. Gałecki, Ważniejsze pasorzyty [!] ludzkie wewnętrzne i zewnętrzne, Warszawa 1902; tenże, Wykład popularny o suchotach płucnych: istota, choroby, środki zapobiegawcze i zasady leczenia, Warszawa 1905; J. Drzewiecki, Mięso czy pokarmy roślinne? Wskazówki djetetycznego odżywiania się, Warszawa 1904; K. Łazarowicz, Co to jest cholera i jak ją zwalczać, Warszawa 1905; B. Marchlewska, Co każdy o hygienie wiedzieć powinien. Mieszkanie i odzież pod względem hygjenicznym, Warszawa 1903.

${ }_{33}$ K. Niedzielski, Uwagi i rady lekarza przydatne w życiu codziennem, Warszawa 1905.

${ }^{34}$ B. Handelsman, Wskazówki dla rodziców i wychowawców dotyczące pielęgnowania zdrowia uczącej się młodzieży, Warszawa 1907; B. Korybut-Daszkiewicz, Pielęgnowanie chorego dziecka, Warszawa 1907.

35 J. Bączkiewicz, O żywieniu niemowląt, Warszawa 1905; tenże, Jak ochraniać zdrowie niemowląt, Warszawa 1906; tenże, Jak ochraniać dzieci od chorób zakaźnych, Warszawa 1906. 
Podobne cele, związane z upowszechnianiem wiedzy wśród szerokiego grona odbiorców, miały realizować tomy dotyczące różnych aspektów nauk o wychowaniu. Badania pedagogiczne i psychologiczne rozwijały się w drugiej połowie XIX w. bardzo prężnie, potężny był dorobek zachodnioeuropejskiego pisarstwa naukowego w tej dziedzinie. Powstawało także szereg polskich oryginalnych prac naukowych z tego zakresu, będących rezultatem refleksji teoretycznej i badań empirycznych nad uwarunkowaniami procesów wychowawczych. Rozwijającym się polskim badaniom naukowym towarzyszyło dążenie specjalistów do popularyzacji wiedzy pedagogicznej i psychologicznej. W serii wydawanej przez M. Arcta opublikowano szereg tomów dotyczących zasad psychologii i pedagogiki, zarówno autorstwa polskich specjalistów, jak i tłumaczenia prac obcojęzycznych ${ }^{36}$.

Dział dotyczący tych zagadnień pełnił istotną rolę, miał służyć upowszechnianiu założeń nowej pedagogiki. Publikowane opracowania w założeniu autorów i wydawcy miały być pomocą w samokształceniu nauczycieli początkowych i rodziców. Poruszano różne zagadnienia, wiele uwagi poświęcano kwestiom dotychczas tabuizowanym, problemom, o których we wcześniejszym okresie ze względów obyczajowych i społecznych nie pisano, a które duża część specjalistów uznawała za istotne i wymagające opracowania przez teoretyków i spopularyzowania wśród rodziców i nauczycieli. Jednym z takich zagadnień była np. sprawa wychowania seksualnego. Opublikowano m.in. popularny poradnik Ellis Ethelmer zatytułowany Skąd się wziął twój braciszek?, który był jedną z pierwszych wydanych po polsku książek dla szerokiego odbiorcy dotyczących uświadamiania seksualnego dzieci ${ }^{37}$. Znacznie istotniejszą rolę w zakresie uświadomienia samych rodziców co do znaczenia wychowania seksualnego spełniły książki Izy Moszczeńskiej, która opublikowała w ramach serii „Książek dla Wszystkich” tomy poświęcone temu problemowi: Co każda matka swojej dorastającej córce powiedzieć powinna, Jak rozmawiać z dziećmi o kwestyach drażliwych: wskazówki dla mate $^{38}$. Pisarstwo Moszczeńskiej miało za zadanie zwrócić uwagę rodziców na problem seksualności młodzieży, pozostający niemal całkowicie poza wiedzą i zainteresowaniem rodziny. Tymczasem wyniki badań empirycznych pokazywały, jak powszechna wśród chłopców jest wczesna inicjacja seksualna. Moszczeńska w 1904 r. opisała wyniki ankiety o uświadomieniu seksualnym chłopców, zastrzegając, że praca „w założeniu swym nie miała być sensacyjną, lecz pouczającą”. Wyniki mogły budzić niepokój, bowiem w badanej grupie 134 chłopców wiedzę na temat seksualności 98 zdobyło od rówieśników, 15 od służby, 12 drogą

36 Zob. np. S. Brzozowski, Zasady psychologii popularnie wyłożone, Warszawa 1904; A. Brzozowska-Kolberg, Fizyczne wychowanie dzieci, podług Jędrzeja Śniadeckiego i in., Warszawa 1902; F. Adler, O kształceniu młodzieży w poczuciu obowiązku, Warszawa 1905; A. J. Fournier, Dla naszych synów, gdy dojdą do dojrzałości fizycznej, Warszawa 1905; M. Egidy, Wychowanie dzisiejsze, Warszawa 1902; K. Kalinowski, O charakterze i jego kształceniu, Warszawa 1908; S. Kopczyński, Higjena i szkoła, Warszawa 1905; R. Skowroński, Ruch i ćwiczenia cielesne, Warszawa 1901; J. Ochorowicz, O kształceniu własnego charakteru, Warszawa 1907; H. Wernic, Wychowanie dziecka do lat 6-ciu, Warszawa 1902.

37 E. Ellis, Skąd się wziął twój braciszek?, Warszawa 1905.

38 I. Moszczeńska, Co każda matka swojej dorastającej córce powiedzieć powinna, Warszawa 1904; taż, Jak rozmawiać z dziećmi o kwestyach drażliwych: wskazówki dla matek, Warszawa 1904. 
dedukcji i domysłu, 4 od starszego rodzeństwa, 1 od bony, 1 na skutek naocznej obserwacji, 3 w połączeniu z pierwszą próbą. W dwóch przypadkach wiedza została przekazana przez rodziców ${ }^{39}$. Moszczeńska przekonywała, że niezbędne jest prowadzenie najpierw w środowisku rodzinnym wychowania seksualnego, istotnego z punktu widzenia zdrowotnego, społecznego i moralnego. Większość rodziców nie była jednak przygotowana do prowadzenia rozmów z dziećmi i młodzieżą na temat seksualności i prokreacji, dlatego tak ważne było opublikowanie przystępnych bedekerów mogących pomóc w przygotowaniu się do właściwego poprowadzenia rozmów na temat płciowości. Wydawnictwa popularne, takie jak tomiki „Książek dla Wszystkich” miały pomóc w uświadomieniu rodzicom i wychowawcom konieczności przełamania indolencji środowiska rodzinnego i szkoły w zakresie wychowania seksualnego. Podkreślano potrzebę racjonalizacji procesu edukacji seksualnej, by uchronić młode pokolenie przed demoralizacją i chorobami wenerycznymi. Iza Moszczeńska opublikowała w ramach serii „Książki dla Wszystkich" także inne tomy dotyczące wychowania. Cenną pracą było popularne kompendium Dla rodziców rady i wskazówki przy wychowywaniu dziecito. Autorka przedstawiała w nim w przystępnej formie problemy wychowania fizycznego, umysłowego, moralnego i estetycznego, opierając się na aktualnych wynikach badań pedagogicznych.

W ramach omawianej serii w zakresie nauk o wychowaniu publikowano nie tylko książki o charakterze popularnych poradników, ale także prace mające przybliżać ściśle naukowe aspekty zagadnień pedagogicznych i psychologicznych. Bardzo wartościowe było np. opracowanie autorstwa Anieli Szycówny, organizatorki psychologiczno-pedagogicznych badań nad dzieckiem. Tom wydany w ramach „Książek dla Wszystkich” pod tytułem Jak badać umysł dziecka stanowił pokłosie referatu Szycówny, wygłoszonego na IX Zjeździe Polskich Przyrodników i Lekarzy w 1900 r. w Krakowie. Po raz pierwszy ukazał się drukiem w 1901 r. pod tytułem $O$ zadaniach $i$ metodach psychologii dziecka. Po ogłoszeniu go po raz pierwszy wywołał duże zainteresowanie specjalistów, którzy uznali tekst za programowy dla badań nad psychologią dziecka. Celem drugiego wydania, ukazującego się w ramach popularnej serii wydawniczej, jak pisała sama autorka, było „obznajmić ogół rodziców, wychowawców i nauczycieli z potrzebą systematycznych badań nad dziećmi, a zarazem dać im wskazówki co do sposobu ich prowadzenia”. Autorka podkreślała utylitarność swojej pracy: „Starałam się pisać dostępnie tak, iżby rzecz była zrozumiałą dla przeciętnej matki lub nauczyciela początkowego [...]"41. Tom poświęcony przyczynom, przejawom i możliwościom zapobiegania nerwowości dzieci opublikował wybitny neurolog i prekursor neuropsychiatrii dziecięcej w Polsce, doktor Władysław Sterling ${ }^{42}$. W ramach serii

\footnotetext{
39 Taż, Czego nie wiemy o naszych synach. Fakta i cyfry dla użytku rodziców, Warszawa 1904, s. 25.

40 Taż, Dla rodziców rady i wskazówki przy wychowywaniu dzieci, Warszawa 1903; taż, Reformy w wychowaniu moralnem: Odczyt publiczny, Warszawa 1903; taż, Dobre i złe wychowanie dzieci w przykładach, Warszawa 1904.

${ }^{41}$ A. Szycówna, Jak badać umysł dziecka (O zadaniach i metodach psychologii dziecka), Warszawa 1904, s. 4.

42 W. Sterling, Dziecko nerwowe, Warszawa 1903.
} 
podejmowano także trudne problemy oświaty; tom dotyczący koedukacji opublikowała Teodora Męczkowska, nauczycielka, działaczka społeczna, feministka ${ }^{43}$.

W ramach omawianej serii wydano także kilka wartościowych prac poświęconych problemom ówczesnego społeczeństwa polskiego, w tym kwestiom patologii społecznych. Zenon Pietkiewicz, ceniony publicysta, literat, ekonomista i tłumacz, był autorem tomu Walka z nędzą, w którym przedstawił położenie najuboższych grup ludności ${ }^{44}$. Pietkiewicz analizował warunki egzystencji najbiedniejszych Polaków, zwłaszcza mieszkańców Warszawy, porównując skalę ubóstwa na ziemiach polskich z jego rozmiarami w krajach zachodnich, a przede wszystkim przybliżając działania instytucji filantropijnych w Europie Zachodniej i Stanach Zjednoczonych. Problem szkodliwości alkoholizmu, w wymiarze indywidualnym i społecznym, podjęła Zofia Daszyńska-Golińska, zagorzała zwolenniczka abstynencji ${ }^{45}$.

W serii zaprezentowano wiele cennych opracowań, zarówno oryginalnych polskich, jak i tłumaczeń obcojęzycznych prac. Wydawano także streszczenia tekstów obcych pisarzy; i tak np. Maria Buyno-Arctowa opracowała kilka tomów poświęconych wychowaniu moralnemu na podstawie prac niemieckiego pedagoga i etyka Friedricha Wilhelma Foerstera, autora popularnych poradników dla rodziców i wychowawców ${ }^{46}$. Prace wybitnych zachodnich specjalistów tłumaczyła także Iza Moszczeńska, w przekładzie której w ramach serii ukazały się m.in. Zagadnienia praktyczne z psychologii wychowawczej Oscara Altenburga ${ }^{47}$. Cenne prace specjalistów tłumaczyła Zofia Sennewald, która przełożyła wydane w ramach serii książki Wychowanie dzisiejsze M. von Egidy, Duszę dziecka M. de Fleury, Wychowanie wychowawcy C. G. Salzmanna ${ }^{48}$.

Tomiki wydawane w ramach serii „Książki dla Wszystkich” miały za zadanie popularyzację nauki na poziomie średnim. Wiele tomów napisanych było na tyle przystępnie, że mogli je czytać nawet odbiorcy z elementarnym przygotowaniem. Seria wydawana przez wydawnictwa M. Arcta z założenia, zgodnie z nazwą, miała egalitarny charakter i realizowała utylitarne cele. S. Arct pisał: „"Książki dla Wszystkich», pomyślane jako biblioteczka popularna dla szerokich kręgów czytelniczych, zawierały materiał do samouctwa, do dopełnienia wiedzy w zaniedbanych wówczas dziedzinach i do nauki życia". Dalej zaznaczał, że chociaż ich „pierwotnym programem było położenie nacisku na dziedziny życia praktycznego, przerodziły się w bibliotekę uniwersalną"49.

Ważnym elementem była niska cena; choć nie udało się utrzymać ceny 10 czy 20 kopiejek za tom, to nadal w porównaniu z wieloma innymi wydawnictwami była

${ }^{43}$ T. M. Męczkowska, Szkoły mieszane: (Koedukacja), Warszawa 1906.

44 Z. Pietkiewicz, Walka z nędzą, Warszawa 1907.

45 Anty. Al. Koholik [Z. Daszyńska-Golińska], Pijaństwo nasz wróg, Warszawa 1905.

${ }^{46} \mathrm{~W}$ tłumaczeniu bądź streszczeniu Marii Buyno-Arctowej ukazało się kilka prac F. W. Foerstera, m.in. Nauka życia w przykładach: książka dla rodziców, wychowawców i nauczycieli, t. 1-3, Warszawa 1906, 1912, 1913; tenże, Nauka życia: pogadanki etyczne, Warszawa 1911.

47 O. Altenburg, Zagadnienia praktyczne z psychologii wychowawczej, Warszawa 1902.

48 M. von Egidy, Wychowanie dzisiejsze, Warszawa 1902; M. de Fleury, Dusza dziecka, Warszawa 1904; C. G. Salzmann, Wychowanie wychowawcy, Warszawa 1904.

49 S. Arct, Okruchy..., s. 183-184. 
ona przystępna. Droższe były te opatrzone kolorowymi rycinami. Cena tomów wzrastała w kolejnych latach, zawsze uzależniona była od objętości, charakteru publikacji, rodzaju oprawy. I tak np. stosunkowo drogie były książki służące do nauki języków obcych - słowniki i rozmowy (rozmowy polsko-angielskie, polsko-francuskie, polsko-niemieckie, polsko-rosyjskie). Wydawane w ramach serii książki, z przyczyn zarówno społecznych, jak i komercyjnych, miały trafić do jak najszerszego grona odbiorców, stanowić środek oddziaływania na społeczeństwo. Masowy nakład i niski koszt tomów serii powodował, że nie miały one elitarnego charakteru, typowego dla prestiżowych wydawnictw, przeciwnie - stanowiły rodzaj drukowanych odczytów, przystępnych poradników, podręcznych bedekerów. Jednocześnie oferowano także do zawieszenia na ścianie „półeczki dębowe do „Książek dla Wszystkich”, z dwoma lub trzema przedziałami, o szerokości 35 lub $53 \mathrm{~cm}$. Ich zakup umożliwiał wyeksponowanie domowej biblioteczki, a wystawienie w ten sposób podręcznej kolekcji nie tylko pomagało w uporządkowaniu zbioru, ale także służyło legitymacji poziomu kulturalnego domu, było zewnętrznym symbolem aspiracji i stylu spędzania czasu wolnego. Jednocześnie skromna objętość, popularny charakter i niska cena sprawiały, że książki z arctowskiej serii kupowano zapewne nie dla wypełnienia funkcji dekoracyjno-prestiżowej, ale dla ich wartości treściowej ${ }^{50}$.

Jak wspomniano, problemem serii był nierówny poziom merytoryczny poszczególnych tomów. Niektóre cieszyły się zgodnym uznaniem krytyki, niektóre natomiast wzbudzały ożywioną dyskusję. Tak było np. w przypadku tomu pt. Hygiena wieku szkolnego, napisanego przez J. Trumppa, a opracowanego przez W. Sterlinga, wydanego w ramach serii „Książki dla Wszystkich” w 1908 r. ${ }^{51} \mathrm{Na}$ łamach „Nowych Torów” w 1909 r. rozgorzała dyskusja między doktorem W. Sterlingiem, tłumaczem i autorem opracowania (wydanie polskie zostało nieznacznie skrócone w stosunku do oryginału) a doktorem W. Miklaszewskim, który uważał, że wydany tomik jest nieudanym przykładem popularyzacji wiedzy z uwagi na jego niski poziom merytoryczny, odwoływanie się do nieaktualnego stanu nauki, niedokładność podawanych informacji i nieprecyzyjny język. Zdaniem recenzenta, publikowanie tego rodzaju prac jest przejawem groźnej mody powoływania się na zagraniczne autorytety, „co nie jest argumentem w sprawach, w których należałoby mieć zdanie samoistne, oparte na badaniach własnych. Wszak obskurantyzm polega właśnie na hołdowaniu autorytetom"52. Autor przekładu w replice stwierdzał, że tłumaczona praca w oryginale wydana była również w ramach serii obejmującej prace wybitnych lekarzy i higienistów, klinicystów i teoretyków, wychodzącej pod redakcją słynnego monachijskiego higienisty Grubera. Jej celem miało być przybliżenie pracy Trumppa, tłumaczonej na kilka języków, także polskim czytelnikom.

Jeśli seria „Książki dla Wszystkich” przeznaczona była dla masowego odbiorcy, to kolejna seria wydawnicza M. Arcta, „Biblioteczka Dzieł Ekonomiczno-Spo-

50 Por. A. Moczulska, Rola książki jako przedmiotu w domach burżuazji warszawskiej w XIX wieku, „Kwartalnik Historii Kultury Materialnej” 1979, nr 1, s. 38.

51 J. Trumpp, Hygiena wieku szkolnego, oprac. W. Sterling, Warszawa 1908.

52 W. Miklaszewski, Odpowiedź, „Nowe Tory” 1909, nr 3, s. 253. 
łecznych", miała odmienny charakter. Była przeznaczona dla wykształconego czytelnika. Redaktorem serii została wspomniana już wcześniej Zofia Daszyńska-Golińska, która od czasu studiów równolegle z działalnością naukową zajmowała się twórczością publicystyczną i popularyzatorską. Jej teksty przybliżały ustalenia nauki zachodnioeuropejskiej, dotyczyły najważniejszych problemów ówczesnego świata, co umożliwiało polskim czytelnikom poznanie zagadnień ważnych dla opinii publicznej w Europie i poglądów zachodnioeuropejskich intelektualistów. Samej autorce natomiast pozwalało na rozwijanie umiejętności pisania tekstów publicystycznych, poszerzanie horyzontów naukowych, wreszcie zapewniało środki utrzymania. Tego rodzaju motywacje były zresztą znamienne dla większości autorów współpracujących z wydawnictwem M. Arcta. Pisząc z powodów idealistycznych i praktycznych, Daszyńska zwracała uwagę na wartość popularyzowania nauki. Pisała, że „rola pojedyńczego badacza nie staje się przez popularyzacyę mniej ważną. Badacz przez popularyzacyę nauki nie traci bynajmniej swojego znaczenia"53. Przekonywała, że wiedza nie powinna być zarezerwowana dla elit, ale stać się dobrem ogólnodostępnym i pospolitym, motorem wszelkich konstruktywnych zmian społecznych i gospodarczych.

Podejmując działania na rzecz publikacji serii „Biblioteczka Dzieł Ekonomiczno-Społecznych", Daszyńska podkreślała konieczność połączenia teorii intelektualistów Zachodu z osiągnięciami polskich uczonych. Założeniem serii było przybliżenie Polakom nieznanego poza wąskim gronem specjalistów dorobku polskich intelektualistów tworzących w XVIII i XIX w. W ramach serii w latach 1911-1919 opublikowanych zostało 11 tomów przedstawiających wybitne dzieła znakomitych ekonomistów i myślicieli: Fryderyka Skarbka, Józefa Supińskiego, Henryka Kamieńskiego, Hugona Kołłątaja, Józefa Marii Hoene-Wrońskiego, Waleriana Strojnowskiego, Ferdynanda Naxa, Stanisława Staszica, Wawrzyńca Surowieckiego ${ }^{54}$. Celem serii było przedstawienie koncepcji ekonomicznych i społecznych polskich intelektualistów, by wykazać i spopularyzować wartości polskich osiągnięć naukowych. W założeniu Zofii Daszyńskiej-Golińskiej ważne było także „wykazanie wspólności ekonomicznej trzech zaborów”55 oraz zachowanie łączności ponadzaborowej Polaków, integralności polskiej nauki i kultury. Wspomniana seria miała te zadania ułatwić. Niestety, od początku inicjatywa wydawnicza borykała się z problemami wynikającymi z małej pokupności ${ }^{56}$. W 1913 r. zawieszono wydawanie kolejnych tomów, ale w następnych latach udało się wznowić tę cenną

53 Z. Daszyńska-Golińska, Szkice metodologiczne, Warszawa 1892, s. 23.

54 F. Skarbek, Ogólne zasady nauki gospodarstwa narodowego, 1911; J. Supiński, Szkoła polska gospodarstwa społecznego, 1911; H. Kamieński, Filozofia ekonomii materialnej społeczeństwa ludzkiego, 1911; H. Kołłątaj, Porządek fizyczno-moralny, 1912; M. Hoene-Wroński, Mylne systemy ekonomii politycznej, 1912; tenże, System ekonomiczno-przemysłowy Adama Smitha, 1912; W. Strojnowski, Ekonomia krajowa powszechna narodów, 1912; F. Nax, Wykład początkowych prawideł ekonomii politycznej, 1914; S. Staszic, Przestrogi dla Polski, 1916; W. Surowiecki, Miasta i rzemiosła w Polsce, 1918; S. Staszic, Uwagi nad życiem Jana Zamoyskiego, 1919.

55 Z. Daszyńska-Golińska, Pionierka wiedzy społeczno-politycznej w Polsce. Notatki autobiograficzne, Kraków 1932, s. 23.

56 R. Owadowska, Zofia Daszyńska-Golińska. O nurt reformistyczny w polityce społecznej, Poznań 2004, s. 58-59. 
serię i wydać kilka części. W porównaniu z serią „Książek dla Wszystkich” „Biblioteczka Dzieł Ekonomiczno-Społecznych" miała charakter bardziej koneserski, była adresowana do osób mających pewną profesjonalną wiedzę.

Obie omawiane serie znacząco wzbogaciły dorobek wydawniczy oficyny M. Arcta. Miały istotne znaczenie dla popularyzacji nauki, gdyż docierały do różnych grup odbiorców, o różnym stopniu przygotowania. Odegrały wielką rolę nie tylko w upowszechnianiu wiedzy, ale także - jeśli nie przede wszystkim - w budowaniu społecznego klimatu sprzyjającego zainteresowaniu różnymi dyscyplinami nauki, co z jednej strony miało wartości autoteliczne, z drugiej służyło demokratyzowaniu społeczeństwa i nauki. Anonimowy publicysta „Przyrody i Przemysłu” w 1873 r., pisząc o społecznej roli popularyzatora nauki, podkreślał, iż musi on „rzucać mosty nad dotychczasowymi przepaściami społecznymi” ${ }^{2}$. Stanisław Kramsztyk na łamach „Nowych Torów” w 1907 r. zwracał uwagę na przewagę wydawnictw drukowanych nad publicznymi wykładami. Pisał: „odczyt zadanie swe spełni, gdy głód wiedzy rozbudzi i podsyci; zaspokoić go może słowo drukowane dopiero, które najłatwiej wszędzie przenika i najtrwalsze ślady pozostawia. Rozwój piśmiennictwa popularnonaukowego stać się winien ważnym zadaniem chwili bieżącej"58.

Wydawnictwo M. Arcta dążyło przede wszystkim do realizacji pozytywistycznych idei, zakładających modernizację społeczeństwa dzięki szerzeniu wiedzy, walce z przesądami i zacofaniem, poprawie ogólnej świadomości jak najszerszych grup ludności. Wzrost popularności scjentyzmu, przekonanie o wielkiej roli nauki przyczyniły się do zwiększenia zainteresowania literaturą popularnonaukową i naukową; omawiane serie wychodziły naprzeciw społecznym potrzebom w tej dziedzinie. W obliczu niedostatków systemu edukacyjnego zasadniczą rolę odgrywało samokształcenie, a znaczenie literatury upowszechniającej naukę wydawało się szczególnie istotne ${ }^{59}$. Popularyzatorami współpracującymi z wydawnictwem M. Arcta byli często wybitni specjaliści; również dla nich możliwość opublikowania tekstów adresowanych do szerokiego odbiorcy była ważna i cenna, dawała szansę na upowszechnienie wyników badań, co w ogólnym wymiarze przyczyniało się do poszerzenia społecznej roli uczonych i zwiększenia prestiżu nauki.

${ }^{57}$ Cyt. za: J. Kurczewska, Społeczny wzór uczonego na podstawie warszawskiej prasy pozytywistycznej, [w:] Inteligencja polska XIX i XX wieku. Studia 4, red. R. Czepulis-Rasztenis, Warszawa 1985, s. 160.

58 S. Kramsztyk, O popularyzacji nauki, „Nowe Tory” 1907, nr 3, s. 241.

59 K. R. Ż., Nasze życie umysłowe, „Prawda” 1900, nr 47, s. 560-561. 